\title{
Pengembangan MARION 4.0 pada Materi Bangun Ruang untuk Pembelajaran Inovasi di Era New Normal
}

\author{
Prima Yudhi ${ }^{1}$, Yuliani Fitri ${ }^{2}$ \\ ${ }^{1}$ Program Studi Pendidikan Matematika, FKIP, Universitas Muhammadiyah Sumatera Barat, \\ ${ }^{2}$ Program Studi Pendidikan Matematika, FKIP, Universitas Ekasakti Padang, \\ Jl. Pasir Jambak No 04, Padang, Indonesia \\ primayudhi@ymail.com
}

\begin{abstract}
The research aims to produce interactive multimedia tutorials as an effort to enhance education 4.0, which will be the new normal in the post-COVID-19 digital age in the future. Because of their relative complexity, geometrical solid objects are used to implement learning. It's hard to learn when, in general, geometric concepts are visualized through static images. A student needs careful reasoning to understand the concept of a lesson through experimentation. As a result, there is not enough time for learning. This research is used in research and development, which refers to the Instructional Development Institute (IDI) model, which consists of three stages, namely: define or analysis of needs, development, and evaluation. The subject of the study is a limited class of 30 SMPN 1 Padang students in the VIII.C class. The research results yielded a valid MARION 4.0, which has been valued in terms of content and constructs. While examining, high practical tests showed the ease of use and increased interest in learning, and students became more active in the following learning. Improvement in complete learning can reach up to $76.67 \%$. Based on these circumstances, it was determined that the developed MARION 4.0 is valid, practical, and effective as a medium for learning innovations in the class VIII junior high school.
\end{abstract}

Keywords: Geometrical Solid Objects, Interactive Multimedia Tutorial, New Normal, Learning Innovation

\begin{abstract}
Abstrak
Penelitian ini bertujuan menghasilkan multimedia tutorial interaktif sebagai upaya menyongsong pendidikan 4.0 yang akan menjadi new normal di era digital pasca COVID-19 nantinya. Implementasi dilakukan dalam pembelajaran materi bangun ruang, karena materi tersebut memiliki kompleksitas relatif tinggi. Pembelajarannya menjadi sulit ketika umumnya pemaparan konsep divisualisasikan melalui gambar-gambar statis. Peserta didik membutuhkan penalaran yang cermat mengenai konsep-konsep materi dengan melakukan banyak percobaan. Akibatnya alokasi waktu pembelajaran masih belum mencukupi. Penelitian ini merupakan penelitian pengembangan (developmental research) dan mengacu pada model Instructional Development Institute (IDI) yang terdiri atas tiga tahap, yaitu penentuan (define) atau analisis kebutuhan, pengembangan (develop) dan evaluasi (evaluate). Subjek penelitian pada kelas terbatas berjumlah 30 orang peserta didik SMPN 1 Padang Panjang pada kelas VIII.C. Hasil pengembangan berupa MARION 4.0 memperoleh kevalidan dari segi isi dan konstruk, sedangkan dari uji praktikalitas menunjukkan kemudahan penggunaan yang tinggi, minat belajar meningkat, dan peserta didik lebih aktif dalam belajar. Peningkatan ketuntasan hasil belajar peserta didik mencapai hingga 76,67\%. Berdasarkan kondisi tersebut disimpulkan bahwa MARION 4.0 yang dikembangkan telah valid, praktis dan efektif digunakan sebagai media pembelajaran inovasi untuk peserta didik kelas VIII Sekolah Menengah Pertama.
\end{abstract}

Kata kunci: Bangun Ruang, Multimedia Tutorial Interaktif, New Normal, Pembelajaran Inovasi

Copyright (c) 2022 Prima Yudhi, Yuliani Fitri

$\triangle$ Corresponding author: Prima Yudhi

Email Address: primayudhi@ymail.com (J1. Pasir Jambak No 04, Padang, Indonesia)

Received 04 Desember 2021, Accepted 03 January 2022, Published 06 January 2022

\section{PENDAHULUAN}

Setelah berakhirnya pandemi global coronavirus (COVID-19), peserta didik akan kembali ke sekolah dengan menerapkan protokol new normal pada setiap pelaksanaan pembelajaran. Sehingga nantinya semua guru harus mampu mengintegrasikan kombinasi proses pembelajaran pada semua ruang belajar (tatap muka, tatap maya, mandiri dan kolaboratif) (Chaeruman, 2020). Pendidikan 4.0 
telah berkembang pada premis dasar. Ruang kelas online telah memfasilitasi pembelajaran dengan lebih banyak cara daripada yang pernah kita bayangkan. Namun di sisi lain, guru juga mempunyai tantangan dan tuntutan implementasi kurikulum merdeka belajar melalui pembelajaran aktif yang berorientasi pada peserta didik (student-centered active learning) dan pembelajaran yang lebih bersifat personal (personalized learning).

Pendidikan sekarang dipandang lebih sebagai proses seumur hidup daripada ritual yang berorientasi pada kelas atau dalam hal ini hanya sekedar batu loncatan ke dunia profesional. Peserta didik dan guru sekarang akan mencari cara untuk mendefinisikan kembali cara-cara dimana pembelajaran selalu mempengaruhi kehidupan mereka. Pada era pendidikan 4.0, di tengah pesatnya teknologi informasi maka "produksi inovasi" menjadi sangat penting khususnya untuk dunia pendidikan. Hal tersebut dapat dilakukan melalui pengembangan tiga inovasi literasi baru diantaranya yaitu 1) literasi data yang berkaitan dengan kemampuan membaca, dan menganalisis, hingga memanfaatkan informasi berupa big data dalam dunia digital, 2) literasi teknologi yang berkaitan dengan teknis operasional sebuah mesin, hingga teknologi dalam sebuah aplikasi, dan 3) literasi manusia yang berkaitan dengan aspek humanities, komunikasi dan desain (Camilleri, 2018). Pendidikan 4.0 memiliki fokus pada pemanfaatan teknologi dalam proses pembelajaran, sehingga pembelajaran dilakukan secara berkelanjutan tanpa harus hadir dan berinteraksi secara langsung di kelas. Artinya pelaksanaan dari ruang kelas, sudah terjadi pergeseran pola belajar menuju kearah dimanapun dan kapan saja, dari waktu rutin terjadwal ke real-time, dari fasilitas konstruksi ke fasilitas fiber jaringan, hingga dari pensil dan kertas menuju online (Rosenberg, 2001). Penerapan sistem pendidikan 4.0 memiliki ciri pada: self-directed (setiap kebutuhan peserta didik harus menjadi alasan terjadinya proses pembelajaran), adanya multi-sources (menggunakan berbagai media dan sumber daya pembelajaran), life-long learning (pembelajaran hingga akhir hayat), pembelajaran menggunakan teknologi informasi, motivasi, sikap terhadap perubahan, diadaptasi dengan mudah, memiliki growth mindset tetapi bukan fixed mindset (Wibawa, 2018).

Salah satu bentuk inovasi berbasis teknologi yang berorientasi pada peserta didik (studentcentered active learning) dan bersifat personal (personalized learning), dapat berupa perancangan sebuah media pembelajaran matematika berdasarkan kebutuhan peserta didik. Matematika memiliki karakteristik yang abstrak, sehingga dalam upaya memahami konsep-konsepnya memerlukan upaya dan keseriusan konsentrasi yang tinggi bahkan membutuhkan waktu yang cukup lama, penuh dengan simbol dan notasi yang sedikit sulit untuk dipahami (Hartinah Ds \& Setiawan, 2013; Mustamid \& Raharjo, 2015). Banyak hal abstrak dalam materi matematika yang dapat dipresentasikan melalui simulasi Teknologi Informasi dan Komunikasi (TIK).

Media pembelajaran inovatif berbasis TIK dapat memberikan pengalaman belajar yang senantiasa terus meningkat, baik dalam artian kompetensi peserta didik dalam berpikir (dari LOT hingga sampai pada tingkat High Order Thinking atau HOT), maupun meningkat pada penguatan 
karakter melalui pembiasaan dan peningkatan kemampuan literasi (Koesnandar, 2020).

Penggunaan multimedia interaktif sebagai bentuk pembelajaran inovatif adalah suatu sistem penyampaian pembelajaran yang merekam visual, suara dan video yang dipresentasikan kepada peserta didik dibawah kendali komputer, dimana peserta didik tidak hanya dapat melihat gambar dan mendengar suara, tetapi juga memberi respon aktif dimana respon tersebut mempengaruhi langkah serta urutan penyajian presentasi (Smaldino et al., 2019; Vaughan, 2006). Hal ini juga didukung oleh (Phillips, 1997) bahwa multimedia interaktif menggambarkan aliran baru dalam teknologi perangkat lunak komputer yang berkaitan erat dengan penyampaian informasi. Komponen multimedia dicirikan dengan adanya tulisan, gambar, suara, animasi dan video yang terpadu dalam satu program. Komponen interaktif mengacu pada proses pengontrolan penggunaan program oleh peserta didik.

Beberapa penelitian yang sudah dilakukan berkaitan dengan penggunaan multimedia interaktif diantaranya dilakukan oleh (Kurnia, 2019) dalam pembelajaran pemecahan masalah menggunakan media interaktif dengan model tutorial, dapat meningkatkan hasil belajar matematika peserta didik pada materi SPLDV. Penelitian (Karimah et al., 2017) yang menunjukkan efektifitas software berupa animasi berbasis multimedia interaktif model tutorial pada materi garis dan sudut. Kemudian juga ada pengembangan oleh (Arifin, 2017) berupa pengembangan tutorial berbasis multimedia interaktif yang dapat membantu peserta didik dalam membangun pemahaman konsep matematis secara mandiri.

Hasil penelitian tersebut sesuai dengan pendapat yang dikemukakan oleh (Barron \& Orwig, 1995) bahwa keuntungan serta keefektifan dari suatu Multimedia Interactive Tutorial Learning (MARION) adalah meningkatkan hasil belajar dan rasa percaya diri, mempersingkat waktu pembelajaran, menghemat biaya, menciptakan pembelajaran yang aktif, mampu memfasilitasi gaya belajar serta kemampuan peserta didik yang berbeda-beda, meningkatkan motivasi dan mendorong peserta didik bereksplorasi dengan rasa aman.

Berdasarkan uraian diatas, terlihat betapa pentingnya mengadaptasi kebiasaan baru dalam pembelajaran pasca COVID-19 bercirikan sistem pembelajaran 4.0 khususnya pada objek geometri seperti materi tiga dimensi bangun ruang. Materi tersebut memiliki kompleksitas yang cukup tinggi, membutuhkan penalaran dan analisis secara cermat sehingga perlu melakukan percobaan yang memakan banyak waktu dalam pembelajarannya. Penggunaan MARION yang memanfaatkan visualisasi, animasi dan ilustrasi pada materi tersebut dapat meningkatkan pemahaman dan kemampuan personal peserta didik secara teoritis, praktis, maupun visual (Altıparmak, 2014; Milovanovi et al., 2013). Sehingga keefektifan pembelajaran dapat meningkat dengan alokasi waktu yang tersedia.

\section{METODE}

Penelitian ini menggunakan metode Research and Development dengan model prosedural Instructional Development Institute (IDI) yang merupakan sebuah hasil konsorsium antar perguruan 
tinggi di Amerika Serikat yang dikenal dengan University Consorsium Instructional Development and Technology (UCIDT). Model ini menerapkan prinsip pendekatan sistem, yaitu penemuan (define) atau analisis kebutuhan, pengembangan (develop) dan evaluasi (evaluate). Setiap tahapan tersebut dikaitkan dengan umpan balik (feedback) untuk melakukan perbaikan. Model IDI dipilih karena sesuai dengan masalah yang melatarbelakangi penelitian ini. Dengan adanya analisis kebutuhan, diharapkan dengan model ini dapat dikembangkan MARION 4.0 yang valid, praktis dan efektif dalam meningkatkan hasil belajar matematika. Adapun prosedur pengembangan disajikan pada gambar berikut.

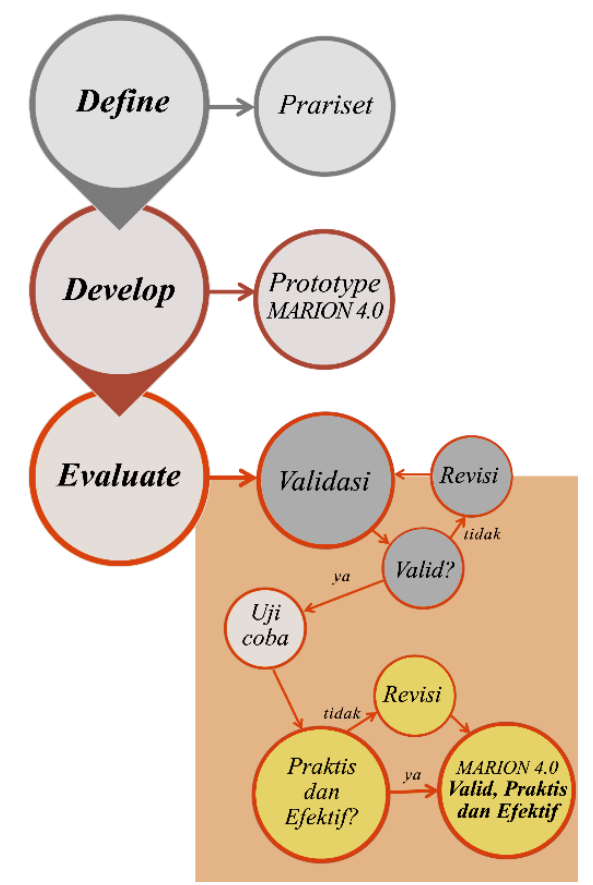

Gambar 1. Prosedur Pengembangan IDI (Sumber: (Vanderhoven \& Schellens, 2011)

Penelitian dilakukan di SMPN 1 Padang Panjang, dengan subjek ujicoba lapangan berjumlah 30 orang peserta didik kelas VIII.C pada semester genap tahun pelajaran 2020/2021. Subjek dipilih sebagai sampel menggunakan teknik purposive sampling karena peserta didik pada kelas tersebut memiliki kemampuan yang heterogen, lebih aktif dan kooperatif saat Pembelajaran Jarak Jauh (PJJ).

Prototype MARION 4.0 dan instrumen penelitian telah melalui tahap validasi ahli oleh 6 validator yang terdiri dari 5 dosen dan 1 guru. Proses validasi dan diskusi dengan validator dilakukan berkalikali sampai pada akhirnya protoype dan instrumen tersebut memiliki tingkat validitas yang baik. Instrumen yang digunakan dalam penelitian ini berupa pedoman wawancara, angket, dan soal tes. Wawancara guru dilakukan untuk mengetahui mengetahui masalah atau fenomena apa saja yang dihadapi dilapangan sehubungan dengan proses pembelajaran matematika peserta didik. Penyebaran angket meliputi tiga tahap, yaitu angket analisis kebutuhan peserta didik, angket validasi dan angket respon peserta didik. Instrumen angket analisis kebutuhan bertujuan mengumpulkan data mengenai kebutuhan peserta didik pada sebuah media pembelajaran. Instrumen angket validasi ini dipakai untuk 
mengukur tingkat validitas produk yang dihasilkan sebagai media pembelajaran. Sedangkan angket respon peserta didik digunakan untuk mengukur tingkat keterpakaian atau praktikalitas produk. Tingkat efektifitas produk diukur melalui hasil tes belajar menggunakan perhitungan persentase peserta didik yang memenuhi Kriteria Ketuntasan Minimal (KKM) yang dipakai oleh sekolah tersebut. Data yang diperoleh melalui berbagai instrumen diatas dianalisis secara kualitatif dan kuantitatif.

\section{HASIL DAN DISKUSI}

\section{Tahap Penentuan (Define) atau Analisis Kebutuhan}

Pada tahapan ini dilakukan beberapa kegiatan analisis muka-belakang untuk mengetahui kondisi sebenarnya dilapangan. Kegiatan dimulai dari observasi proses pembelajaran dan dilanjutkan sesi wawancara guru setelahnya. Analisis terhadap silabus dan buku teks juga dilakukan untuk menganalisis keterkaitannya dengan Kompetensi Inti (KI) dan Kompetensi Dasar (KD) pada pokok bahasan yang menjadi objek.

Berdasarkan hasil wawancara diketahui bahwa pembelajaran masih didominasi oleh peran aktif guru. Disamping itu, alokasi waktu untuk pembelajaran matematika yang tersedia masih belum mencukupi, dan biasanya pembelajaran materi bangun ruang sebagai materi terakhir disemester 2 sering tidak tuntas sehingga pembelajaran hanya sebatas pada kisi-kisi ujian akhir semester, akibatnya peserta didik kesulitan memahami konsep dalam materi tersebut. Ketika dikondisikan dalam sebuah masalah yang menuntut penyelesaian secara individual, peserta didik justru menyontek pekerjaan temannya dan hanya beberapa peserta didik saja yang mengerjakan sendiri. Buku teks yang digunakan peserta didik memuat materi bangun ruang, tetapi belum bisa membuat peserta didik memahami konsep. Akibat peserta didik tidak memahami konsep dan cenderung menghafal rumus sehingga peserta didik bingung ketika dihadapkan dengan variasi soal. Materi tiga dimensi tersebut perlu divisualisasikan agar konsep menjadi mudah dipahami. Dalam tahapan ini ditentukan format solusi untuk masalah dan hambatan yang sudah dihimpun dilapangan.

\section{Tahap Pengembangan (Develop)}

Perencanaan desain produk yang dikembangkan berupa perangkat lunak penunjang konstruksi konsep pembelajaran bangun ruang berbasis e-learning. Storyboard dirancang sebagai acuan peneliti dalam merancang setiap lembar halaman yang terdapat pada multimedia pembelajaran tutorial interaktif. Rancangan setiap menu utama pada MARION 4.0 dijelaskan secara terperinci, baik dari segi warna latar maupun tombol navigasi, gambar latar, tulisan, maupun berbagai tautan (link) yang digunakan.

Sedangkan untuk struktur program tutorial dirancang dalam bentuk bercabang (branching) dan bermanfaat sebagai acuan peneliti dalam merancang tautan (link) tiap halaman software. Program berupa diagram alir merupakan tahapan-tahapan cara mengeksekusi MARION 4.0 mulai dari intro, 
Pengembangan MARION 4.0 pada Materi Bangun Ruang untuk Pembelajaran Inovasi di Era New Normal, Prima Yudhi, Yuliani Fitri

menu utama, dan ending. MARION 4.0 disajikan menarik berupa kombinasi antara kolom teks, puzzle, musik dan animasi untuk menjelaskan materi yang sedang dipelajari. Peserta didik dapat memilih dan mengulangi sebuah animasi dalam penyajian materi

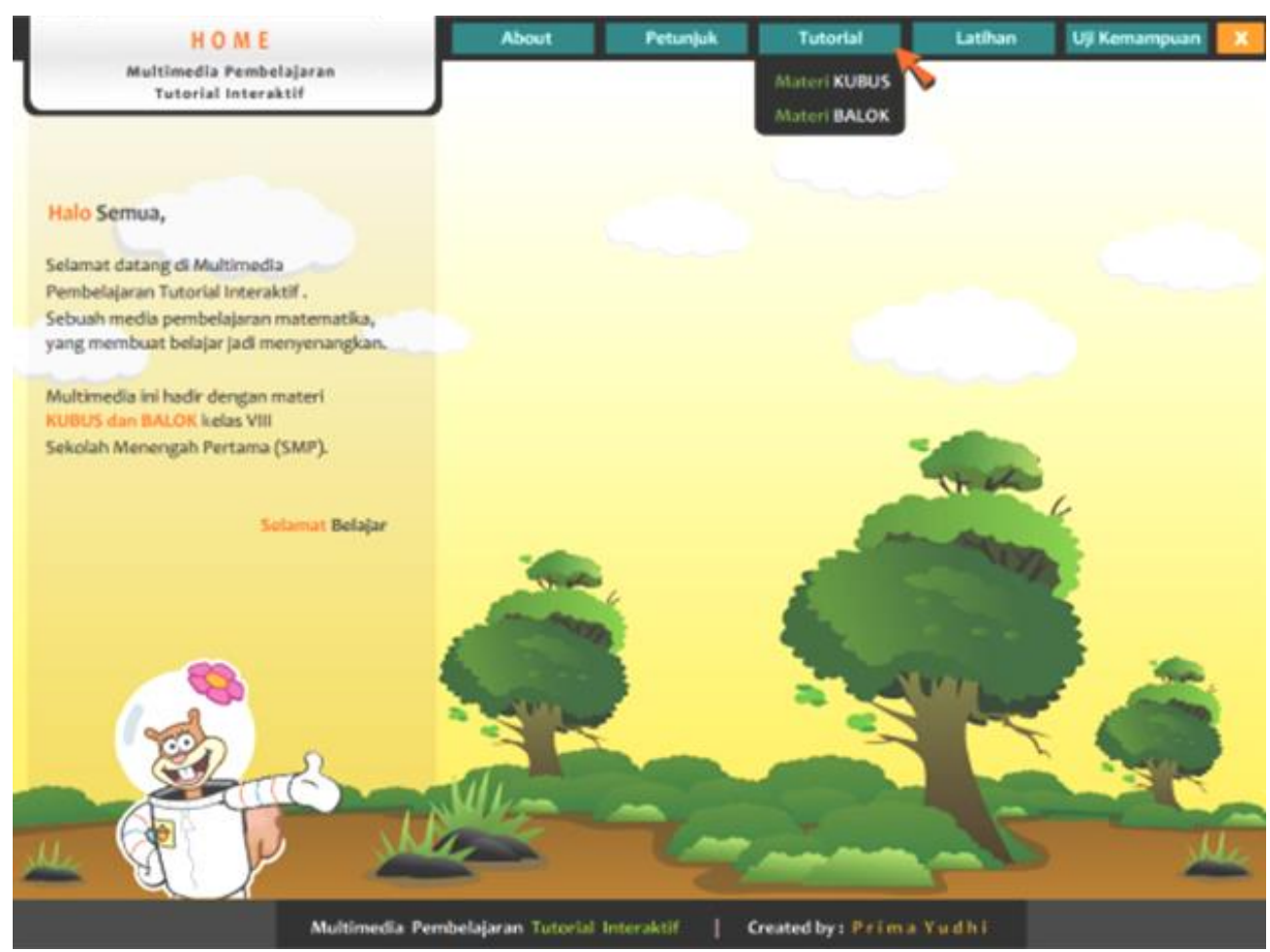

Gambar 2. Halaman Utama MARION 4.0 (Sumber: Produk Pengembangan Penulis)
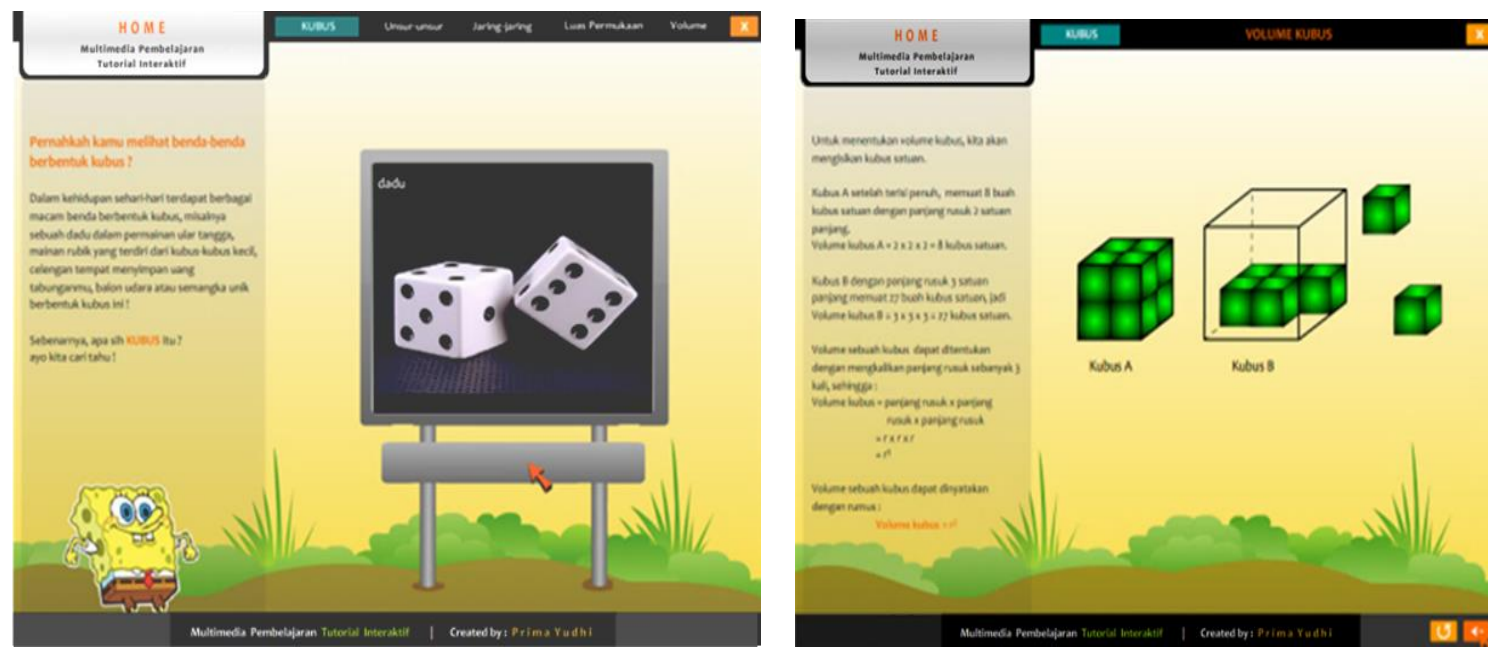

Gambar 3. Halaman pada Salah Satu Submateri (Sumber: Produk Pengembangan Penulis)

Latihan soal yang bersifat interaktif, dimana jawaban setiap soal pilihan ganda direspon berupa animasi ekspresi. Jika peserta didik memberikan jawaban benar maka akan disajikan bentuk penyelesaian soal yang baik, tetapi jika jawaban salah maka akan muncul menu bantuan agar peserta didik dapat mempelajari kembali salah satu konsep berdasarkan jenis kesalahan yang dibuat peserta didik. 


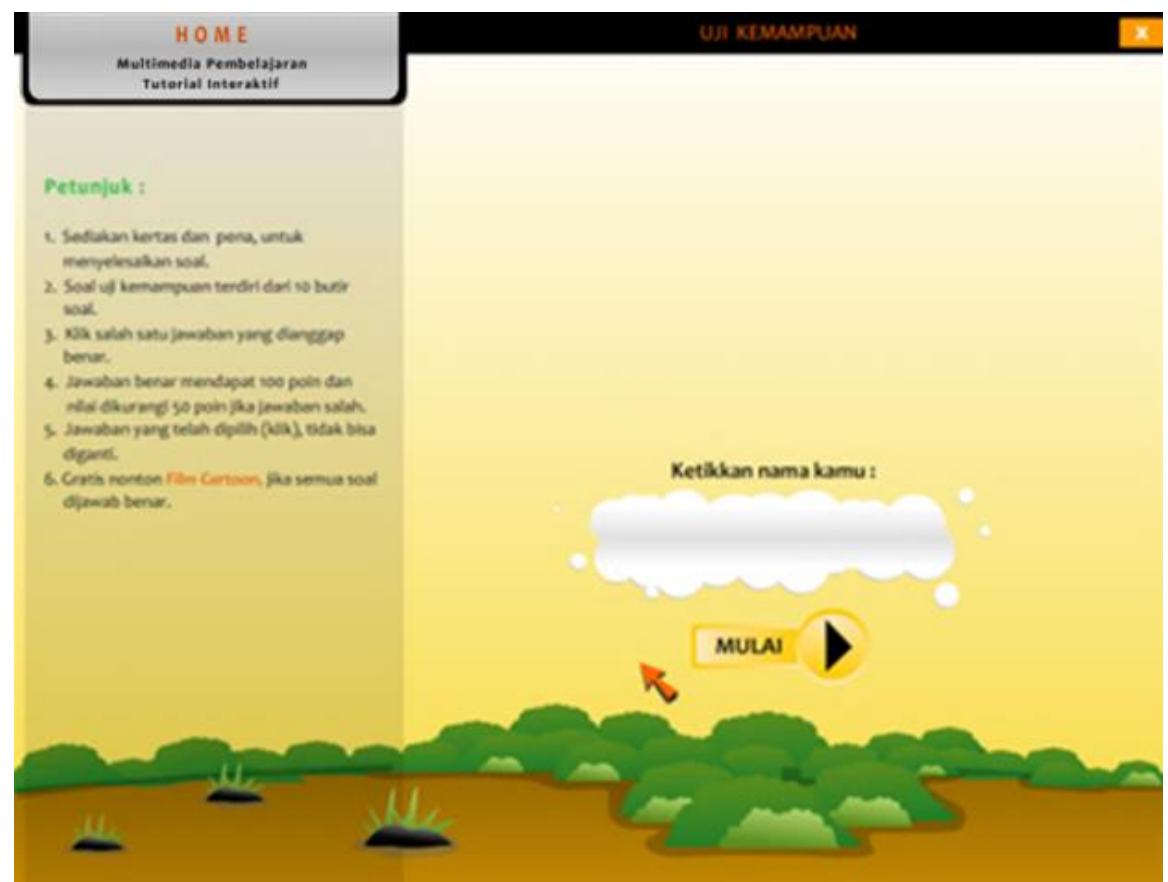

Gambar 4. Halaman Uji Kemampuan (Sumber: Produk Pengembangan Penulis)

Soal uji kemampuan pada MARION 4.0 dapat merespon setiap jawaban dengan akumulasi skor disetiap jawaban soalnya. Peserta didik dengan nilai sempurna mendapatkan reward berupa menonton video kartun edukasi.
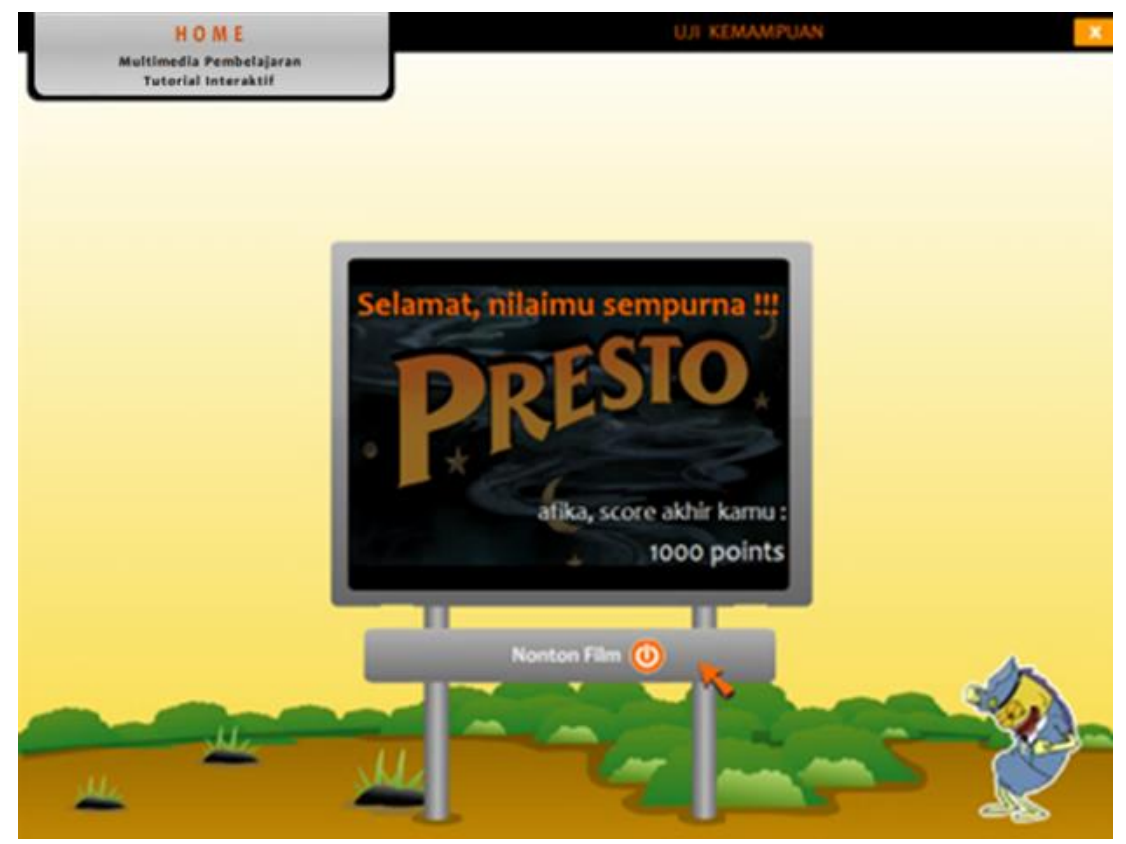

Gambar 5. Halaman Reward Hasil Uji Kemampuan (Sumber: Produk Pengembangan Penulis)

Materi bangun ruang pada MARION 4.0 menyajikan konsep-konsep abstrak agar menjadi kongkret melalui visualisasi animasi gambar bergerak. Peserta didik dapat membangun pengetahuannya sendiri berdasarkan pengalamannya selama menggunakan multimedia interaktif sehingga peserta didik tidak hanya menunggu penjelasan dari guru melainkan bisa menemukan 
Pengembangan MARION 4.0 pada Materi Bangun Ruang untuk Pembelajaran Inovasi di Era New Normal, Prima Yudhi, Yuliani Fitri

konsep sendiri. Peserta didik juga dapat mengulangi materi untuk penguasaan secara menyeluruh dengan belajar sendiri di luar lingkungan sekolah.

\section{Tahap Evaluasi (Evaluate)}

Setelah perancangan prototype MARION 4.0 dilakukan validasi oleh para ahli yang terdiri dari 3 ahli materi matematika dan 3 ahli pengembangan media pembelajaran. Proses validasi dan diskusi dengan para validator menjadi bahan untuk melakukan revisi pada prototype yang menghasilkan prototype berikutnya hingga memiliki kategori valid. Berikut rekapitulasi hasil validasi MARION 4.0 yang dilakukan oleh para ahli.

Tabel 1. Hasil Validitas MARION 4.0 dari Ahli Media

\begin{tabular}{|l|c|c|}
\hline \multicolumn{1}{|c|}{ Aspek } & Rerata Nilai & Kategori \\
\hline Kesederhanaan & $2,40<\mathbf{3 , 0 0} \leq 3,20$ & valid \\
\hline Keterpaduan & $2,40<\mathbf{3 , 0 0} \leq 3,20$ & valid \\
\hline Penekanan & $2,40<\mathbf{2 , 8 4} \leq 3,20$ & valid \\
\hline Keseimbangan & $2,40<\mathbf{2 , 6 7} \leq 3,20$ & valid \\
\hline Bentuk & $2,40<\mathbf{2 , 6 7} \leq 3,20$ & valid \\
\hline Warna & $2,40<\mathbf{2 , 6 7} \leq 3,20$ & valid \\
\hline Rata-rata & $2,40<\mathbf{2 , 8 1} \leq 3,20$ & valid \\
\hline
\end{tabular}

Tabel 2. Hasil Validitas MARION 4.0 dari Ahli Materi

\begin{tabular}{|l|c|c|}
\hline \multicolumn{1}{|c|}{ Aspek } & Rerata Nilai & Kategori \\
\hline Format & $2,40<\mathbf{2 , 9 5} \leq 3,20$ & valid \\
\hline Isi & $2,40<\mathbf{3 , 0 3} \leq 3,20$ & valid \\
\hline Bahasa & $2,40<\mathbf{3 , 0 0} \leq 3,20$ & valid \\
\hline Rata-rata & $2,40<\mathbf{2 , 9 9} \leq 3,20$ & valid \\
\hline
\end{tabular}

Setelah prototype berkategori valid, langkah selanjutnya dilakukan ujicoba terbatas di kelas VIII.C SMPN 1 Padang Panjang. Ujicoba bertujuan untuk melihat praktikalitas dan efektivitas MARION 4.0 dalam pembelajaran. Pengujian praktikalitas dengan pengisian angket praktikalitas melalui respon 30 peserta didik yang telah menggunakan MARION 4.0 pada proses pembelajaran.

Tabel 3. Hasil Uji Praktikalitas MARION 4.0

\begin{tabular}{|l|c|c|}
\hline \multicolumn{1}{|c|}{ Aspek } & Rerata Nilai & Kategori \\
\hline Kesesuaian dengan waktu & $65 \%<\mathbf{7 8 , 7 5 \%} \leq 79 \%$ & praktis \\
\hline Kemudahan menggunakan MARION 4.0 & $80 \%<\mathbf{8 2 , 4 1 \%} \leq 100 \%$ & sangat praktis \\
\hline Manfaat yang didapat peserta didik & $65 \%<\mathbf{7 9 , 4 4 \%} \leq 79 \%$ & praktis \\
\hline Rata-rata & $2,40<2,99 \leq 3,20$ & praktis \\
\hline
\end{tabular}

Materi bangun ruang selesai dibahas dalam empat kali proses pembelajaran, kemudian peserta didik diberikan evaluasi/tes. Tes ini bertujuan untuk melihat hasil kognitif belajar peserta didik disamping itu juga untuk mengetahui tingkat keefektifan MARION 4.0. Uji efektifitas dilakukan melalui pemberian sepuluh soal pilihan ganda dan soal esay sebanyak lima buah sesuai dengan tujuan pembelajaran yang telah dibuat. Seorang peserta didik dikatakan tuntas jika nilai yang diperoleh lebih 
besar atau sama dengan Kriteria Ketuntasan Minimum (KKM) yang ditetapkan sekolah.

Tabel 4. Hasil Uji Efektifitas MARION 4.0

\begin{tabular}{|l|c|}
\hline \multicolumn{1}{|c|}{ Aspek } & Rerata Nilai \\
\hline Nilai Tertinggi & 93 \\
\hline Nilai Terendah & 50 \\
\hline Nilai Rata-rata & 71,34 \\
\hline Tuntas & 23 orang \\
\hline Tidak Tuntas & 7 orang \\
\hline Persentase Ketuntasan & $\mathbf{7 6 , 6 7 \%}$ \\
\hline
\end{tabular}

Berdasarkan data tabel diatas diketahui dari 30 peserta didik, jumlah yang tuntas KKM dengan nilai rata-rata 71,34 sebanyak $76,67 \%$. Artinya bahwa indikator keberhasilan ketuntasan yang diharapkan pada penelitian minimal 70\% sudah tercapai sehingga dapat disimpulkan MARION 4.0 pada materi bangun ruang efektif digunakan dalam pembelajaran.

Penelitian berupa pengembangan multimedia interaktif sebelumnya pernah juga dilakukan, tetapi yang dilakukan hanya memindahkan materi tekstual buku kedalam media software. Media tersebut hanya disertai dengan tombol-tombol yang berfungsi untuk menghubungkan antar slide yang diinginkan oleh pengguna. Pengembangan MARION 4.0 disesuaikan dengan karakteristik multimedia interaktif yang merupakan sebuah sistem komputer hingga memberikan kemudahan untuk menggabungkan teks, data, gambar, video, maupun audio visual animasi yang dilengkapi dengan alat pengontrol yang bisa digunakan pengguna, sehingga pengguna dapat memilih objek yang diinginkan untuk beralih menuju proses selanjutnya (Daryanto, 2016; Rusman, 2013). MARION 4.0 juga disertai beberapa animasi sebagai stimulus motivasi peserta didik untuk mempelajari materi. Simulasi dan visualisasi ruang tiga dimensi materi bangun ruang sangat berkaitan dengan kehidupan sehari-hari yang bisa merangsang cara berfikir peserta didik. Sehingga setelah dilakukan proses validasi oleh para ahli materi matematika dan ahli pengembangan media pembelajaran, MARION 4.0 mempunyai validitas yang baik.

Penggunaan MARION 4.0 sangat mudah, karena dilengkapi petunjuk penggunaan dan materi disajikan menggunakan bahasa yang mudah dipahami peserta didik. Penyajian materi bangun ruang juga dilengkapi dengan animasi pembahasan latihan soal dapat membantu peserta didik meningkatkan pemahaman konsep. MARION 4.0 melatih peserta didik belajar secara mandiri untuk memahami materi pelajaran dalam waktu yang relatif singkat. Sehingga proses pembelajarannya peserta didik tidak banyak membutuhkan bimbingan guru. Bagi peserta didik berkemampuan rendah dapat memahami materi secara berulang-ulang untuk penguasaan secara menyeluruh dengan belajar mandiri. MARION 4.0 memiliki karakteristik multimedia yang mempunyai potensi untuk mengakomodir berbagai bentuk respon yang dihasilkan pengguna, mudah digunakan serta memiliki kelengkapan dari segi isi sehingga dapat digunakan tanpa membutuhkan bimbingan dari orang lain 
(Ariani \& Haryanto, 2010; Daryanto, 2016). Visualisasi objek pada MARION 4.0 memberikan manfaat yang besar bagi perkembangan peserta didik diantaranya adalah meningkatkan pemahaman konsep matematika, membantu peserta didik belajar mandiri dan meningkatkan motivasi peserta didik belajar matematika. Berdasarkan hasil angket respon yang diisi peserta didik sebagai pengguna dalam proses pembelajaran terlihat bahwa penggunaan MARION 4.0 sudah bernilai praktis. Hal ini tampak pada kesesuaian waktu, kemudahan menggunakannya, dan manfaat yang diperolehnya.

Hasil belajar merupakan sesuatu puncak proses belajar. Hasil belajar peserta didik dapat dijadikan tolak ukur penentuan tingkat keberhasilan dalam memahami sebuah pelajaran (Dimyati \& Mudjiono, 2006). Hasil belajar dapat diketahui dengan menggunakan tes. Tes merupakan salah satu alat dalam sebuah evaluasi yang bertujuan untuk mengukur ketercapaian tujuan pembelajaran yang telah ditetapkan (Trianto, 2010). Berdasarkan aktivitas belajar peserta didik dan hasil tes belajar peserta didik tersebut dapat dikatakan bahwa MARION 4.0 pada materi bangun ruang sudah efektif. Artinya, multimedia pembelajaran tutorial interaktif sudah efektif dalam meningkatkan aktivitas positif peserta didik selama proses pembelajaran matematika dan sudah efektif dalam memberikan hasil belajar yang baik, sehingga kompetensi yang diharapkan tetap dapat tercapai meskipun alokasi waktu yang tersedia minim.

\section{KESIMPULAN}

Penelitian pengembangan ini telah menghasilkan sebuah multimedia pembelajaran yang layak berupa MARION 4.0 pada materi bangun ruang. Berdasarkan hasil validasi menunjukkan kevalidan yang baik. Artinya MARION 4.0 telah dinilai berorientasi pada peserta didik (student-centered active learning) dan bersifat personal (personalized learning). Hasil ujicoba yang dilakukan juga menunjukkan bahwa MARION 4.0 praktis digunakan dalam proses pembelajaran, mudah digunakan, petunjuk penggunaannya jelas, dan bahasanya mudah dipahami. Penggunaan MARION 4.0 juga sangat membantu peserta didik dalam proses belajar mandiri, membantu guru dalam proses pembelajaran pada materi dan mampu mengatasi kurangnya alokasi waktu untuk pembelajaran. Penggunaan MARION 4.0 sudah efektif dalam memberikan hasil belajar yang baik sehingga kompetensi yang diharapkan tetap dapat tercapai meskipun alokasi waktu yang tersedia minim.

Pengembangan MARON 4.0 ini juga dapat dilakukan guru pada pokok bahasan lainnya. Halhal yang perlu diperhatikan untuk mengembangkan sebuah multimedia pembelajaran adalah sistim pendidikan, tuntutan kurikulum, karakteristik peserta didik, kesesuaian materi dengan indikator yang akan dicapai. Oleh karena itu, validitas dan praktikalitas serta efektivitas dari multimedia pembelajaran yang dikembangkan tidak boleh diabaikan karena menjadi penentu kualitas yang dihasilkan.

MARION 4.0 dalam proses pengembangannya, peneliti memiliki keterbatasan saat kondisi pandemi sehingga: a) MARION 4.0 hanya diujicobakan pada satu kelas saja, untuk menghasilkan 
produk yang lebih baik diharapkan diujicobakan pada semua kelas VIII tingkat SMP, b) MARION 4.0 sudah efektif dalam meningkatkan hasil belajar peserta didik, tetapi untuk memperoleh hasil yang lebih baik lagi, direkomendasikan untuk melakukan ujicoba kedua terhadap hasil revisi setelah ujicoba pertama.

\section{REFERENSI}

Altiparmak, K. (2014). Impact of Computer Animations In Cognitive Learning: Differentiation. International Journal of Mathematical Education in Science and Technology, 45(8), 11461166.

Ariani, N., \& Haryanto, D. (2010). Pembelajaran Multi Media di Sekolah: Pedoman Pembelajaran Inspiratif, Konstruktif, dan Prospektif . Jakarta: Prestasi Pustaka.

Arifin, A. H. (2017). Pengembangan Tutorial Berbasis Multimedia Interaktif pada Pembelajaran Matematika Ditinjau dari Pemahaman Konsep Matematis Kelas VII SMP Negeri 1 Sedayu. Yogyakarta: Mercubuana.

Barron, A. E., \& Orwig, G. W. (1995). Multimedia Technologies for Training: An Introduction. Englewood: Libraries Unlimited.

Camilleri, P. (2018). Robot-Proof: Higher Education in The Age of Artificial Intelligence. Journal of Education for Teaching, 44(4), 519-520.

Chaeruman, U. A. (2020). Ruang Belajar Baru dan Implikasi Terhadap Pembelajaran di Era Tatanan Baru. Kwangsan: Jurnal Teknologi Pendidikan, 8(1), 142-153.

Daryanto. (2016). Media Pembelajaran: Peranannya Sangat Penting dalam Mencapai Tujuan Pembelajaran. Yogyakarta: Gava Media.

Dimyati, \& Mudjiono. (2006). Belajar dan Pembelajaran. Jakarta: Rineka Cipta.

Hartinah Ds, S., \& Setiawan, T. (2013). Sikap Guru Taman Kanak-Kanak Terhadap Pembelajaran Matematika. Jurnal Ilmu Pendidikan, 19(1), 50-55.

Karimah, A., Rusdi, R., \& Fachruddin, M. (2017). Efektifitas Media Pembelajaran Matematika Menggunakan Software Animasi Berbasis Multimedia Interaktif Model Tutorial pada Materi Garis dan Sudut untuk Siswa SMP/MTS Kelas VII. Jurnal Penelitian Pembelajaran Matematika Sekolah (JP2MS), 1(1), 9-13.

Koesnandar, A. (2020). Pengembangan Model Pembelajaran Inovatif Berbasis Teknologi Informasi dan Komunikasi (TIK) Sesuai Kurikulum 2013. Kwangsan: Jurnal Teknologi Pendidikan, 8(1), $33-63$.

Kurnia, A. (2019). Pembelajaran Pemecahan Masalah dengan Media Interaktif Model Tutorial untuk Meningkatkan Hasil Belajar Matematika Siswa Kelas X Multimedia 3 SMKN 2 Garut Pokok Bahasan Sistem Persamaan Linier Dua Variabel Tahun Pelajaran 2017/2018. Jurnal Petik, 5(2), $62-68$. 
Pengembangan MARION 4.0 pada Materi Bangun Ruang untuk Pembelajaran Inovasi di Era New Normal, Prima Yudhi, Yuliani Fitri

Milovanovi, M., Obradovi, J., Obradovic, J., Rs, I., Milaji, A., Milajic, A., \& Rs, S. (2013). Application of Interactive Multimedia Tools In Teaching Mathematics - Examples of Lessons From Geometry. The Turkish Online Journal of Educational Technology, 12(1), 19-31.

Mustamid, M., \& Raharjo, H. (2015). Pengaruh Efektifitas Multimedia Pembelajaraan Macromedia Flash 8 Terhadap Motivasi Belajar Siswa pada Materi Fungsi Komposisi dan Invers. Eduma: Mathematics Education Learning and Teaching, 4(1), 26-41.

Phillips, R. (1997). The Developer's Handbook to Interactive Multimedia: A Practical Guide For Educational Applications. London: Routledge.

Rosenberg, M. J. (2001). E-Learning: Strategies For Delivering Knowledge In The Digital Age. New York: McGraw-Hill.

Rusman. (2013). Belajar dan Pembelajaran Berbasis Komputer: Mengembangkan Profesionalisme Guru Abad 21. Bandung: Alfabeta.

Smaldino, S. E., Lowther, D. L., Mims, C., \& Russell, J. D. (2019). Instructional Technology and Media for Learning. New York: Pearson Education.

Trianto. (2010). Mendesain Model Pembelajaran Inovatif-Progresif: Konsep, Landasan dan Implementasinya pada Kurikulum Tingkat Satuan Pendidikan (KTSP). Jakarta: Kencana Prenada Media.

Vanderhoven, E., Schellens, T., \& Valcke, M. (2011). Report on Critical Design Guidelines to Consider When Developing Solutions: SPION-Deliverable 7.1. Ghent University, 1-19.

Vaughan, T. (2006). Multimedia: Making It Work. Yogyakarta: Andi Publisher.

Wibawa, S. (2018). Pendidikan dalam Era Revolusi Industri 4.0. Yogyakarta: Universitas Sarjanawiyata Tamansiswa. 